\title{
A Survey of Perspectives on Intergovernmental Relations: A Comparative Analysis of the Czech and Slovak Republics
}

Phillip J. Bryson

phil_bryson@byu.edu

Gary C. Cornia

Scott M. Smith

Follow this and additional works at: https://scholarsarchive.byu.edu/facpub

Part of the Economics Commons

\section{Original Publication Citation}

Phillip J. Bryson, Scott M. Smith and Gary C. Cornia, "'A Survey of Perspectives on Intergovernmental Relations: A Comparative Analysis of the Czech and Slovak Republics,"'" Europe-Asia Studies, Vol. 61, No. 4, June, 29, pp. 685-79. http://www.tandfonline.com/doi/abs/ 1.18/96681392826337\#preview

\section{BYU ScholarsArchive Citation}

Bryson, Phillip J.; Cornia, Gary C.; and Smith, Scott M., "A Survey of Perspectives on Intergovernmental Relations: A Comparative Analysis of the Czech and Slovak Republics" (2009). Faculty Publications. 132. https://scholarsarchive.byu.edu/facpub/132 accepted for inclusion in Faculty Publications by an authorized administrator of BYU ScholarsArchive. For more information, please contact ellen_amatangelo@byu.edu. 


\title{
A Survey of Perspectives on Intergovernmental Relations: A Comparative Analysis of the Czech and Slovak Republics*
}

\author{
Phillip J. Bryson, \\ Gary C. Cornia, \\ and \\ Scott M. Smith
}

\section{Brigham Young University}

\begin{abstract}
:
The results of a survey of local government officials from the Slovak and Czech Republics taken in December of 2005 are presented and analyzed. Attitudes about and perspectives of intergovernmental fiscal relations in the two republics are probed. Differences and similarities in Czech and Slovak views are established regarding some of the perceptions of: local autonomy and the sufficiency of available funds; whether or not public services are supplied by the appropriate levels of government; the potential benefits of adopting a serious rather than a nominal property tax; and the flexibility of local budget planning in Czech and Slovak cities and towns.
\end{abstract}

\section{Classification:}

H1, H77, P3, P35.

\section{Key Words:}

Fiscal decentralization, Public sector transition, Intergovernmental relations, Property tax, Local autonomy, Devolution, Unfunded mandates.

*The authors express gratitude for gracious assistance by the Associations of Cities and Towns in the Czech and Slovak Republics and for financial and other support by the Marriott School of Management and the Lincoln Institute of Land Policy. Any errors or inadequacies remain the sole responsibility of the authors.

\section{Contact Information:}

Phillip J. Bryson, Douglas and Effie Driggs Professor of Economics, 616 TNRB, Marriott School, Brigham Young University, Provo, Utah 84602. USA; Phil_bryson@byu.edu; Tel. 801 422-2526;

Gary C. Cornia is Stewart Grow Professor of Public Management, Department Chairman and Director of the Romney Institute of Public Management, Brigham Young University; Scott M. Smith is James Passey Professor of Marketing at Brigham Young University 


\section{A Survey of Perspectives on Intergovernmental Relations: A Comparative Analysis of the Czech and Slovak Republics:}

\section{Part I.}

\section{Introduction}

The transition from Marxist-Leninist Socialism to market-oriented democracy has been a difficult one for most of the countries of east and central Europe. Many observers view that process as consisting largely of the privatization of state-owned enterprises and the establishment of market relations in the countries involved. But the transition of the public sector in countries once managed by central planning regimes has also been a very important and difficult part of that historic development. The public sector under central planning was highly centralized so that the party could maintain a tight monopoly over the country's decision-making powers. Thus, democratization has required a process of fiscal decentralization to restore some autonomy to local government. Bryson and Cornia (2000) outline the development and difficulties of the initial, somewhat lukewarm attempts of the Slovak and Czech Republics to pursue fiscal decentralization. The efforts of other transition states, reviewed by the OECD (2002), show Hungary, for example, with somewhat greater success than the Czechs and Slovaks have enjoyed, but all the transition countries have struggled in this endeavour. The total level of sub-national revenues and expenditures as a share of GDP has been lower in the transitioning countries than in the earlier members of the EU. The expenditures of the transitional, newer EU members have averaged only 8\% of GDP, whereas they represent $16 \%$ of GDP for the older EU members; the differences in subnational revenues are smaller, but similarly skewed. Subnational revenues represent only 19\% of the GDP of the transitional countries, but 27\% of the GDP of the older members (OECD, 2002, p. 4).

The Czech and Slovak Republics began the process of fiscal decentralization together, but separated in 1993. They then continued along their separate but similar paths and both countries apparently required additional efforts to devolve power. The European Union therefore encouraged them to undergo "reforms of public administration" before their 2004 accession to the community. That period was characterized for both countries by intergovernmental fiscal institutions that reflected a rather high degree of centralism. Consequently, one encounters in the Czech and Slovak Republics these related characteristics - transfers from the centre represent almost a totality of the revenues of local budgets; revenue generation reflects low local fiscal effort; and "own revenues" yields at the level of sub-national government are very modest.

The importance of fiscal decentralization has been acknowledged by both of these young democracies, but the actual accomplishments have been modest. The "reforms of public administration" achieved some positive organizational change in the Czech Republic, but ultimately accomplished little more than the establishment of regional governments (the kraje). In the Slovak Republic reforms were more comprehensive and observers expected a good deal from them. They will be discussed later, but elections and the arrival of a new political coalition in Slovak governance brought some uncertainty as to where the decentralization initiatives would go.

In both countries, the legacies of socialism and the general European disinclination to insist on decentralized political institutions have resulted in the survival of some of the centralism of the previous era. The centre's concern for the many small local governments, which lack the resources adequately to provide for their own 
management, has been at least partially responsible for the development of a fiscal system that can scarcely be described as having achieved fiscal decentralization. In studies sponsored by the World Bank, we find municipal governments in both Republics enjoying only limited autonomy from 1989 to about 2000 (Oliveira and MartinezVazques, 2001 and Bryson and Cornia, 2001). ${ }^{1}$

\section{The Property Tax in the Czech and Slovak Republics}

The primary cause for the lack of genuine municipal autonomy in both republics is the lack of an independent source of revenue. The survey focused at several points on the Czech Real Estate Tax, which is as close to a western property tax as the Republic has been willing or able to come. As a potential independent revenue source, the property tax is a most significant tax for local governments. Although it can give municipalities more autonomous control over their own fiscal affairs, it has not been developed to its potential in either the Czech or Slovak Republic, although the latter has shown a greater willingness to consider serious change in the property tax. It has failed to provide adequate revenues, which it could do with minimal distortion of private allocation processes. Because this tax is highly visible and because Marxist-Leninist regimes were of limited credibility, it was retained at strictly nominal levels during the socialist era. But in spite of this legacy and the natural tendency of any citizenry to oppose property taxes, there is much to recommend them. A tax on real property will make good sense as part of the tax system as a whole because of its efficiency and equity aspects (Oates, 1996)

The country-specific fiscal institutions involved play a major role in determining the effectiveness of a property tax. Who establishes tax policy and who administers the tax are both very important questions. The Slovak Republic retained the basic institutions of the Real Estate Tax after the Velvet Divorce in 1993, one of the most important being that the design of the tax is by the central government. The other important characteristic of the task is that, unlike the Czechs, the Slovaks permitted the municipalities to be responsible for collection of the tax. In the Czech Republic, the centre collects the tax without having strong incentives to do it well (since all the revenue goes to the municipalities.) This unsatisfactory outcome reveals a problem of moral hazard (see Bryson and Cornia, 2003). Slovakia's municipalities harvest their own property tax revenues much more effectively. If all revenues are generated from the centre, will they be made available without the accompanying influence of the centre? Can one speak of genuine fiscal decentralisation if local governments enjoy only limited fiscal autonomy? Central and east Europe's countries in transition have perceived a fairly standard set of taxes and user fees to be well suited for their local governments. The Czechs and Slovaks have not generally felt the property tax should be increased from the low, rather symbolic levels of the communist period. Current levels, however, are not sufficient to fund municipal services or perform the necessary administrative tasks.

If municipalities in the twin republics wish to augment available revenues, they must seek opportunities from sources other than taxation. They may generate revenue from the privatization of public properties or they can incur debt. But the privatisation of public properties exploits a non-recurring revenue source and cannot yield a sustainable cash flow; municipal loans can become dangerously burdensome.

The base and the rate determine the real estate tax yield of both republics. Both land and buildings are included in the base, each being valued separately. National law prescribes the process by which the actual value of property is to be determined; the tax base reflects the floor space of buildings and the area of land plots. Also 
determined by the centre, tax rates differ for buildings and for land. The taxable value of land plots and buildings is basically a function of their areas in square meters, so valuation is not based on market prices. This may have been unavoidable for much of the transition period, but the real estate market has now developed to a point where that could be changed. The tax rate and coefficient for real estate parcels reflect their size, location, and use. These characteristics determine the amount of the real estate tax that will be assessed. In parts of some larger cities, such exemptions represent a major share of the potential tax revenues. There are other instances in the tax policies of transition countries where social welfare concerns have led to exemptions which might imperil the sufficiency of tax revenues. ${ }^{2}$

Table 1 provides a brief history of Czech budgets, both national and local. Although Czech municipal budgets are fairly well funded as compared to other transition countries, Czech cities and towns certainly do not enjoy soft budget constraints. The municipalities of the Slovak Republic have enjoyed greater autonomy, but also enjoy far less revenue. The aggregate of Czech local budgets represented no more than $25 \%$ of the national budget in 1993. That share grew rather continually, although it stagnated at about thirty percent from 1997 through 1999, reaching a high of $32.6 \%$ in the year 2000 .

\section{Table 1 here}

What stands out in the data of Table 1 is the relative insignificance of the real estate tax in the Czech Republic. The state is unwilling to change the property tax, which remains only symbolic and at low levels of revenue. Nor do the local governments successfully apply any pressure on the centre to increase its collection efforts. It is easier simply to accept the revenue-sharing and grants the central government offers. Because the state provides all the revenues for municipal investment projects, it alone determines which projects will be funded. Hope for municipal political independence, obviously a function of the accessibility of independent financial sources, cannot be derived from current Czech intergovernmental fiscal relations. Only in 1994 did real estate tax provide in excess of three percent of the total revenues available to local governments. Otherwise, from 1993 to 2000 its share was between two and three percent. After 2000 the declining proportion fell below two percent. Other municipal revenue sources have increased while the real estate tax decreased. It is important to keep these facts in mind when reviewing local perceptions of intergovernmental fiscal relations; regardless of those perceptions, local Czech budgets provide for as little autonomy as they do for "own funds," i.e., for independent funding sources.

For the Republic of Slovakia, the fiscal story is similar to that of the Czechs; the total revenues going to Slovakia's cities and towns as transfers of shared taxes and grants from the centre have been considerably less generous. Being in charge of their own property tax collections, aggressive Slovak municipalities have generally derived around $10 \%$ of their budget revenues from the real estate tax. The recent reforms of the Slovak government, beginning with the reform of public administration, have been substantially bolder than those of the Czechs. Additional legislation related to fiscal decentralisation was produced in September, 2004 (Ministry of Finance, Republic of Slovakia, 2005). According to the Act on Budgetary Definition of Tax Yield, municipalities receive as their share of the personal income tax, $70.3 \%$ of the revenues of that tax, while the regions ("Upper-tier Territorial Units) $23.5 \%$, and the central government retains only $6.2 \%$. Previously considered subsidies, these are now considered own revenues of the subnational governments. The real estate tax was scheduled to reach about $14 \%$ of 
the revenues of municipal budgets for the year 2007 and the door was opened to greater independence for municipalities in designing their own property tax systems (Bryson and Cornia, 2006).

\section{Genesis of the Survey}

In the course of researching issues of fiscal decentralization and intergovernmental fiscal relations in the twin republics, we had numerous opportunities to hear the views of Finance Ministry and other central government officials. But it seemed important also to gain an understanding of how these issues were perceived by municipal officers. In our limited contacts with them we had received impressions of dissatisfaction with the level of funds they were receiving and with their dependence on the centre for nearly all their revenues. With the help of the associations of cities and towns in the two countries, a questionnaire was developed for mayors and city managers that would reveal some of the important local perceptions and preferences on these fiscal issues. We proceed now by introducing the questionnaire and discussing the participants. We then address four core issues, each being represented by a small set of individual questions:

1. The perceptions of municipal officials on their autonomy and the sufficiency of funds available to them,

2. Whether public services are provided by the appropriate level of government,

3. The potential benefits of adopting a serious rather than a nominal property tax, and

4. The issue of budget flexibility in Czech and Slovak cities and towns.

These issues are addressed in two parts. In Section II we consider survey questions that revealed statistically significant differences between Slovak and Czech responses, whereas Section III reviews questions for which the responses of Czech and Slovak officials did not differ with any statistical significance. Because the two countries began as one, the historical legacy, the laws, customs and traditions that formed many of the municipal leaders were the same. Therefore, differences in attitudes on particular issues would rather closely reflect more recently developing differences in policy and the unique texture of intergovernmental fiscal relations within each of the two countries. Some interesting and important differences are indeed observed in the responses of local officials of the two countries, but the similar histories, traditions, financial situations and backgrounds are similar enough to produce statistically comparable responses in a number of instances. Section IV presents evaluation and conclusions.

\section{The Survey and the Respondents}

A survey of some of the local perceptions of intergovernmental fiscal relations in the Czech and Slovak Republics was designed to solicit the responses of local officials. The questionnaire developed over time and ultimately benefited from extensive input from the Association of Towns and Cities in Bratislava (Združenie miest a obcí Slovenska, or ZMOS) and the Union of Towns and Municipalities of the Czech Republic (Svaz měst a obcí České republiky, or SMO). The questionnaire was taken on line by local Czech and Slovak officials in December of 2005 at the Surveyz.com/Qualtrics.com website. The lion's share of the participants were mayors. There were 84 responses to the Slovak language version and 456 to the Czech language version. ${ }^{3}$ Respondents were asked whether they agreed, agreed strongly, disagreed, disagreed strongly with, or were neutral (unwilling or unable to respond) 
regarding various statements pertaining to the most significant fiscal issues. Some of the questions of the survey were designed to compare some of the perceptions of local leaders to views commonly discussed in the scholarly literature on fiscal decentralization.

The literature on the fiscal situation of sub-national governments in the countries transitioning from central planning regimes to market democracy reports a high degree of fiscal centralization. In the twin republics, transfers from the central government are the dominant, nearly exclusive source of revenues; low local fiscal effort and very meager "own" revenues generated at the municipal level are characteristic. Since the economic transition began in Europe over fifteen years ago, fiscal decentralization has been viewed by the transition literature as essential to democratic development. It is one of the primary means of ensuring the efficiency of public services as government is brought closer to the people (Tanzi 1991; Litvack, Ahmand, and Bird 1998). Decentralization elicits heavy support from the public finance, public choice, and public management literatures (Tiebout 1956; Bish and Kirk 1974) because it makes public decision making more transparent and accountable; it permits citizens to participate effectively and at reasonable cost in local governance (Oates 1998).

Bryson and Cornia (2001, 2001a) have written of the socialist and developmental legacies in Slovakia and of the transformation era in the Czech Republic, emphasizing the centralist traditions of Stalinist economic planning from the previous era and the tendency of most transitional central governments to retain a good deal of directive control. The primary objective of the survey was to determine how participants at the municipal level view intergovernmental relations, i.e., whether from the perspective of local authorities a substantive measure of fiscal decentralization has actually been achieved.

The participants of the survey were from cities and towns of widely diverse sizes; accordingly, the budgets involved ranged from small to very large. There were, however, many more respondents from smaller cities and towns than from the very large cities. Two of the survey's final questions addressed these issues. Here, as in the sections that follow, an analysis of the response follows each question presented.

\section{Question 19. The anticipated receipts of our municipality this year will be approximately CZK (or SKK). Last year's receipts were __ CZK or (SKK).}

Of the Czech respondents, 363 gave an estimate of municipal receipts expected for the year 2005. The average of total anticipated receipts for the Czech Republic's participating cities and towns was approximately 238 million Czech crowns $(\mathrm{CZK}){ }^{4}$ The highest reported receipts were a little over 58 billion CZK, while a few of the very lowest receipts were from around a quarter million $\mathrm{CZK}$ to half a million. For the previous year, average reported receipts had been well over 349 million CZK, so these officials were anticipating smaller receipts for 2005 than for the previous year.

Of the 54 local officials from Slovakia responding to this question, average anticipated receipts for the year were just less than 90 million Slovak crowns (SKK). A small number reported receipts as low as about a quarter million SKK, while the highest reported was 657 million SKK. Average receipts for the previous year had been a little over 85 million SKK. 


\section{Question 20. My position in the municipality.}

Of the Czech respondents, $83 \%$ were mayors, $2 \%$ were city managers, $5 \%$ were financial managers, and the remaining $10 \%$ held other positions. The larger share of the Slovak respondents, $61 \%$, consisted of mayors. Another $7 \%$ were city managers, $21 \%$ were economists and the remaining $11 \%$ filled other positions.

\section{II: The Differences in Slovak and Czech Responses}

We will be concerned in this part about those responses which reflect fundamental perceptive and attitudinal differences between the respondents from the Czech and the Slovak Republics. We will observe that the differences are not generally reflective of fundamental variation in the cultures of these cousin countries, but are usually determined by policy differences in specific situations.

\section{Some perceptions of local autonomy and the sufficiency of the funds available to local officials.}

In this section responses relate to the perceived autonomy of the participants and to their views as to the adequacy of their municipality's level of funding. Since the responsibility of local officials for generating revenues is rather light, especially in the Czech Republic, they need not be terribly concerned about their own fiscal effort in generating revenue yields. They are far more concerned about whether the funds transferred by the central government in the form of shared taxes or grants are sufficient for the provision of public services. A major concern is the provision of funds from the centre to pursue mandated projects and activities. Where demands for services place heavy pressures on local officials, one would expect that they would consider loans, credits and deficit spending as possible means of overcoming fiscal shortfalls. These will also be discussed in this section.

Table 2 here

In the Czech Republic the traditional wisdom of central government officials is that since law prohibits unfunded mandates from the centre, they simply don't occur. Table 2 presents a more realistic picture. When asked whether this traditional wisdom fits their experience, $52 \%$ of local officials disagreed and another $28 \%$ strongly disagreed with the statement. Only $48 \%$ of Slovak respondents disagreed with the observation.

Of Slovak local officials, 38\% agreed that they had not experienced unfunded mandates (as opposed to $11 \%$ of Czech respondents). For this question, a T-test of country differences indicates a statistically significant difference in the means between the Czech and Slovak Republics. Inspection of the significance of Levine's test for equality of variances in Table 3 also shows a statistically significant difference in the variance of the two samples.

Table 3 here

Unfortunately, there are gaps between the reality and the theoretical literature strongly endorsing fiscal decentralization and prescribing at least some measure of local fiscal autonomy as the essential outcome of decentralization. It has been widely perceived that local governments in transition countries have faced burdensome unfunded mandates with woefully inadequate funds (Bahl and Wallace 1994).

Officials of the Czech Finance Ministry deny that unfunded mandates are given to the sub-national governments of the Republic, basically because it is against the law. To "delegate" new responsibilities without transferring the necessary resources to perform them simply increases the demand for transfers or subsidies in 
whatever form. Doing so also tends to keep the municipalities dependent on the central government. Oliveira and Martinez-Vazquez (2001) agree that the Czech Republic has a generally good record for avoiding substantial, unfunded mandates on its local governments. Some projects and activities have been funded through specific grants, which would not have been supplied in some of the other transitioning countries.

There have been, as we note by the responses to the survey, obvious exceptions to the favorable Czech performance. When the responsibility for issuing personal identification cards and passports was transferred to local governments, they objected because the funds were not transferred. Probably the most important case of unfunded mandates in the Czech Republic occurred at the outset of the transition period when the central government transferred the responsibility for and privatization of public housing to local governments. No funds were transferred along with the responsibility to maintain and upgrade the seriously substandard housing stock. Moreover, retaining control over the pricing of transferred service responsibilities only added insult to injury; in effect, it simply supplied another form of unfunded mandate. This kind of policy selection helps explain the soft budget constraint that has to develop for local governments in such a situation as well as the occasional need for bailouts. ${ }^{5}$ Under-funded municipalities cannot be expected to meet financial obligations if imposed financial requirements exceed available funds. They become hostage to their administrative directors in central government, but at the same time they also avoid full financial responsibility for program failures.

The responses to this question are exceptionally interesting. We would have expected that the more generous Czech government would be far less inclined to issue unfunded mandates than the Slovak government. But the Czech respondents far more emphatically disagreed with this survey question's assertion that mandates are not unfunded than did their counterparts from the Slovak Republic. That would mean either that the Czech offenses are more egregious than we would have expected or that Czech officials, less accustomed to the more severe financial struggles of the Slovaks, have a more negative perception than justified by the reality.

When Czech local leaders were asked whether they had sufficient revenues to cover their municipality's operating costs, 63\% agreed (and another 11\% agreed strongly) that they did. As Table 4 shows, only 50\% of Slovak Local Leaders agreed (and another $2 \%$ agreed strongly) that their revenues covered operating costs, while $40 \%$

Table 4 here

disagreed. It is significant that $25 \%$ of the Czech respondents complained of budgets too small to cover operating costs. The Slovak Republic's budgets, smaller yet, caused $40 \%$ of respondents to claim inability to cover operating costs from their budgets. That represents substantial deviation from the Czech responses. This is the first question to which the Czech and Slovak local official responses differed significantly. This is the first of the questions for which a T-test of country differences indicates a statistically significant difference in the means between the Czech and Slovak Republics. Levine's test for equality of variances reported in Table 5, however, shows no statistically significant difference in group variances.

Table 5 here 


\section{Whether the mix of public services assigned to government levels is appropriate.}

This section of the survey also inquired as to whether the local governments of the twin republics supply some services that would be more logically and effectively provided at a higher governmental level. On the other hand, central governments sometimes provide services that would be better provided by subnational governments. This issue is addressed by Questions 8 and 9, reviewed in Table 6. Interestingly, these questions could have been expected to encounter controversial views among the respondents, since in both countries the state routinely performs local service provision functions under the rubric "state administration."

The foundation documents of both countries define state administration as the set of municipal and subnational governance functions assigned to and performed strictly under the direction of the central government. Municipal and regional "self-government" (samospravy) consists of the remainder of the local functions actually assigned to the subnational governments to perform. It is important to recognize that the sovereignty of subnational governments is restricted to the performance of that limited set of constitutionally assigned functions and services.

It is thus somewhat ironic that twenty two percent of Czech respondents thought some of the services their municipality supplies would be better supplied by regional or central government. Fifty-four percent felt that none of the services they supplied could be better supplied by a higher level of government. Of Slovak local officials, a similar share, $31 \%$, thought some of their services would be better supplied by regional or central government. A much larger 52\% felt that none of the services they supply would be better supplied by the central or regional governments. Only $29 \%$ of local Slovak officials felt none of the services supplied by their municipality could actually be better supplied by a higher level of government. That a strong minority of the officials of both countries believe they supply some services that should be supplied by higher levels is indicative of the thorough entrenchment of the notion of state administration. These people would even extend the list of municipal tasks confiscated by the central government from local jurisdiction. Even more surprising is the fact that substantial minorities in both countries see some services that they believe would be better supplied by the regions or by the central government.

Table 6 here

T-tests of the means of the samples of the two republics demonstrated a statistically significant difference, as expected, since a glance at the two country responses shows nearly $80 \%$ of Czechs disagreeing or disagreeing strongly with the statement that local governments never supply services better supplied by the central or regional government. Levine's test is significant $(\mathrm{F}=3.938, \mathrm{P}=.048$, Mean.cz $=2.63$, Mean.sl $=2.73$, Slovakia's standard error is large).

\section{The potential benefits of adopting a serious rather than a nominal property tax.}

It is unlikely that a country's municipalities could enjoy fiscal autonomy while remaining totally dependent upon revenues provided by the central government. The centre may be willing to provide such revenues, but it may well attach spending directives to them. The attached strings imply less local autonomy. This section reviews how a property tax of considerably greater significance than the almost strictly symbolical one currently imposed in the Czech and Slovak Republics might be received and perceived by local authorities. Both republics have basically 
three sources of own revenues: the real estate tax, a limited menu of local taxes and fees, and the sale of public properties. As currently constituted, none of these provide significant amounts of revenues; local fees provide well under 5\% of local revenues and public properties sales cannot continue indefinitely to provide revenues. Therefore, if a genuine, substantive property tax were introduced in these countries, autonomous local revenues would clearly be increased. The fundamental question here is whether a local authority has a revenue source or sources independent of the central government.

Question 13. Roughly what share of total revenues is derived from transfers from the central government? This item is designed to give an indication as to the level of accessible own revenues municipalities enjoy. A fairly large number of the survey participants, both Czech and Slovak, failed to respond to this question, although the request was for an approximation or even an impression rather than an accurate, documentable answer. For the 310 Czechs who did respond, however, the mean of the estimates was that 56.9 per cent of total revenues came through transfers from the central government. Taking an average of the responses of fifty-three local officials from Slovakia, $58.5 \%$ of their municipalities' total revenues came in the form of central government transfers.

What share of the total transfers received could be spent strictly at the discretion of local officials?

We were tempted not to report on question 13, since only thirty-one Czechs and 22 Slovaks responded. One has to reflect on why so few responded to such an important question. Perhaps many had not really thought about this issue. Perhaps some felt that they couldn't answer accurately with the precision that they might have felt the question deserves. Some may have simply wanted "not to go there" because the question is a sensitive one. Statistically speaking, there were enough responses to review. The average of their subjective estimates of the nonmandated expenditures was $51.3 \%$. The 22 responding Slovak local officials provided an average estimate of the share of those transfers not encumbered by mandates of 36.6\%. Levine's test for equality of variances in Table 7 showed statistically significant differences between the Czech and Slovak groups' responses $(\mathrm{F}=5.604, \mathrm{P}=0.018)$.

Table 7 here

An inquiry concerning impressions about what shares of transfers carry mandates is likely to produce a rather subjective response. In some instances a mandate will not explicitly accompany a transfer, but will nevertheless be understood and generally adhered to. The less fiscally-humble Czech municipal officers may be more prepared on occasion to give their government the benefit of the doubt. If this survey was such an occasion, the statistical difference might reflect an impression more than a reality. But such subjectivism aside, we have evidence here of a significantly smaller portion of transfers in the Czech Republic bearing mandates.

Question 12. If we had a real estate tax similar to that in England or the United States, it should be administered by local government, regional government (not included in Czech version), central government

Czech Republic: Local government, 63\%; Central government, $37 \%$

Slovak Republic: Central government, $0 \%$; Regional government, $10 \%$; Local Government, $90 \%$

The difference in these responses is large. Over a third of the Czech respondents did not believe a property tax should be locally administered. This is doubtless because the Czech central government administers the tax, collecting the revenue and redistributing it to the municipalities. And the Czechs receive only nominal revenues from the property tax, but receive enough other revenues from the centre to feel compensated on net. Their response 
seems to reflect an attitude that own revenues are not a concern if the government provides sufficient revenues from other sources.

The Slovaks collect their own property tax and have made strong efforts to maximize the revenues thus derived. None of the Slovak respondents felt that the central government should administer the property tax and 90\% felt that local governments should do so. As seen in Table 8, the t-test for mean differences in the two samples reveals a statistically significant difference in the two countries' responses. Moreover, Levine's test of difference in sample variances shows that equal variances likewise should not be assumed. Thus, the Czech and Slovak responses

Table 8 here

to this question were as from two distinctly separate populations. It would appear that local politicians generally accept the institutional rules of the game as played in their country, sometimes even coming to the point of view that such local institutions are unquestionably right and proper.

Still, consensus thinking is that successful decentralization requires more than just forming subnational governments; it also requires that those governments have access to funding for basic services and even to a local and autonomous source of funding (Kelly 1994). This implies that local governments should administrate the property tax. The public finance literature suggests that the property tax embodies the positive characteristics required of a local tax. It is the economist's local tax of choice because its base is immobile, its revenue is stable, economically it is potentially neutral, and politically it is visible (Musgrave 1993 and Oates 1996). The tax assignment literature accepts the property tax as the ideal local tax (McClure 1983).

It is not surprising that over a third of Czech municipal offers are not averse to the current system, which requires no fiscal effort on their part. Having become accustomed to having their funds simply appear and bearing responsibility only for expenditures, many feel that this is the way the world should work. Virtually none of the Slovak respondents felt that central government should bear the responsibility of managing the property tax, although ten percent would not be averse to having the regional government accept the responsibility.

\section{Table 9 here}

The fundamental question is whether a local authority has a revenue source or sources independent of the central government. When confronted by Question 11 about the property tax (see Table 9), 47\% of Czech officials agreed that it has the potential of being a source of "considerable revenue" for local governments, and another 19\% said they strongly agreed. A large $24 \%$, however, declared they were unable or unwilling to say whether they were in agreement or disagreement. An almost identical $67 \%$ of Slovak local officials felt the property tax could be a source of considerable revenue with 12 percent strongly agreeing. An almost identically large group of $26 \%$ agreed with the $24 \%$ of Czech respondents who were unable or unwilling to say.

Only $18 \%$ of the Czech respondents disagreed with the proposition that revenues from a property tax would have greater value (assuring greater autonomy) than the same amount of shared taxes transferred from the central government (with probable strings attached). The responses appear in Table $9.42 \%$ agreed and another 10\% agreed strongly about the potential value of the real estate tax; a large $29 \%$ were undecided. Of the Slovak respondents, who have been far more dependent upon property tax revenues than the Czechs, only $34 \%$ agreed that the revenues from a decentralized property tax would be of greater worth than shared taxes transferred from the centre. $36 \%$ of 
Slovak local officials disagreed (twice as large a share as in the Czech Republic) that such revenues would be better than shared taxes and $31 \%$ were undecided. An informed interpretation of these responses would have to take into account that the Slovaks have been heavily dependent on property tax yields and have actually been involved in the Table 10 here

collection of the revenues. To be spared the heavy effort thus expended would be appreciated. In this respect a large, costless transfer of funds from the central government would be a better outcome. The symbolic cost of significant tax revenue efforts may be artificially high for the Czechs, not having ever actually been forced to make them. A property tax may be of more value to those who perceive that it allows greater decision autonomy.

For the responses to this question, a t-test for divergent means reveals a statistically significant difference in the mean responses of the two countries. The Levine test (Table 10) did not show a significant difference in variance $(\mathrm{F}=.569, \mathrm{P}=.451)$.

\section{The Similarities in Czech and Slovak Survey Responses}

\section{Perceptions of local autonomy and the sufficiency of the funds available to local officials.}

Our discussion in this section will follow the same ordering of the core issues or complexes of questions. We now address a different set of responses, viz, those showing no statistically significant differences between the local officials of the Czech and Slovak Republics. For the responses of this section, T-tests for differences in means revealed no significant difference in sample means for Czech and Slovak respondents.

The first question, reviewed in Table 11, is the most general one posed on the issue of municipal autonomy. It appears to have been, without considerable reflection, interpreted as: "Despite any potential action of the centre, do I have a meaningful job to do? Do I have important decisions to make?" No less than $67 \%$ of all Czech respondents agreed with this statement (27\% of these did so strongly). Of all the Slovak local leaders, $67 \%$ were also in agreement (11\% of these strongly).

Table 11's more specific questions 2 and 10 appear to have stimulated more reflection and the focus of these questions was not seen as the decision functions of the local leaders but as the system which gave them less autonomy than they would like. Of Czech respondents, $84 \%$ agreed (33\% strongly) that their autonomy would be "much greater" if they were not so dependent upon the centre for financial flows. Only $11 \%$ disagreed with this assertion. Slovak local leaders were likewise in agreement (55\% agreed and another 25\% agreed strongly), so that a total of $80 \%$ thought independence would be much greater if financial dependence were less. ${ }^{6}$

The literature suggests that little real decentralization had been achieved through most of the transition period and that the municipal governments of the Czech and Slovak Republics from 1989 to 2000 or so enjoyed little autonomy, with the picture changing somewhat in terms of its promise since then.

Returning to the theme of local autonomy, question 10 evoked a 52\% Czech response that, despite facing many required expenditures, they have sufficient funds to enjoy "budget autonomy and discretion." A strong 45\% could not agree that they have budget autonomy. This is in clear contrast to the response to question 1. In part, this question was to test whether some local officials might confuse autonomy with budget sufficiency, which some 
appear to have done. Of local officials in Slovakia, only $40 \%$ felt they had such autonomy. Once again, we see the impact of the smaller Slovak municipal budgets on local officials' views in that country.

Table 11 here

Autonomy is, of course, largely a subjective perception. Local governments enjoying fiscal autonomy will likely experience a significant measure of political autonomy. There may be instances, however, where a healthy measure of political autonomy is possible even without independent fiscal resources. Given a substantial democratic tradition like that, for example, of the Netherlands, local authorities will confidently insist on political autonomy, even if they receive most of their funds from central authority. Central authority will rarely attempt to mandate its own preferences on local provision of public goods and services. But where the tradition is a centralist, nondemocratic one, it is far less likely to be overcome by having the centre provide all the funding of local goods and services. Central authority in formerly communist countries was not accustomed to restraints on powers and preferences and local authorities were not inclined to demand the autonomy they lost for forty to sixty years of central planning (Bryson and Cornia 2002).

Question 3 intentionally lacks precision. Its focus is on a subjective perception, so it is not significant precisely what tasks were to be accomplished or who held the expectations mentioned. Of the Czech local leaders $52 \%$ disagreed with the assertion and another $34 \%$ disagreed strongly. Only $12 \%$ agreed that they always had sufficient funds. Of the Slovak respondents, $85 \%$ disagreed with the query (of these $27 \%$ disagreed strongly). As with municipal officials generally, there is clear insistence here that the budget is too small, and the Czechs, whose budgets are considerably larger, obviously felt no less strongly than the Slovaks.

The public finance and fiscal decentralization literatures likewise make reference to the scarcity of resources available to sub-national governments, a condition holding especially in the Slovak Republic during the transition period. The condition stems back to the legacies and fiscal patterns established in the central planning period (see Bird, Ebel and Wallich 1998 and Matoušková 1998). It has already been established that a problem of moral hazard affects local fund-raising efforts negatively when municipalities can neither monitor nor influence central collections efforts (Bryson and Cornia 2003).

The public finance and fiscal decentralization literatures likewise make reference to the scarcity of resources available to sub-national governments, especially in the Slovak Republic, during the transition period. The condition stems back to the legacies and fiscal patterns established in the central planning period (see Bird, Ebel and Wallich 1998) and (Matoušková 1998). As mentioned earlier, a problem of moral hazard affects local fund-raising efforts negatively when municipalities can neither monitor nor influence central property tax collection efforts (Bryson and Cornia 2003).

When queried whether funds from all sources have permitted investments in capital facilities for "necessary functions," (Table 10, question 5) only $26 \%$ of Czech local officials were in agreement. A total of $71 \%$ disagreed, of which $20 \%$ were in strong disagreement. Of Slovak local officials, only $21 \%$ agreed that they could make such investments. $77 \%$ of them disagreed (61\% disagreed and another $16 \%$ disagreed strongly) with the proposition. Here again there is divergence for the two countries. The more modest Slovak budgets left Slovak local officials slightly more strongly in disagreement with this proposition. Nevertheless, t-tests of differences in means and 
variances on the responses to this question by the two countries were not significantly different. So even though the Czech municipalities have enjoyed significantly greater resources from transferred taxes and subsidies, they have not perceived themselves better endowed with funds for investments in capital facilities. An explicit comparison of the municipal and central government budgets of the two Republics in the transition period shows that the Czech municipalities have enjoyed substantially greater revenues through transfers and subsidies than their less affluent Slovak counterparts (Bryson and Cornia 2003, and Bryson, Cornia and Wheeler 2004).

Question 7 on the debt burden of the Czech Republic (see Table 12) lies outside the question sets on core issues, but as one of the pillars of fiscal decentralization has obvious significance in its own right. Of Czech respondents, $83 \%$ considered the level of local debt not to be inappropriate; they indicated that current debt levels are not problematical in the fulfilment of municipal financial obligations (23\% agreed strongly that this is the case). Only $14 \%$ saw local debt as a financial problem for the municipalities. In Slovakia,

Table 12 here

$62 \%$ of those responding to the questionnaire felt that debt was not a significant problem for municipalities and another $15 \%$ felt that way strongly. Only $17 \%$ saw municipal debt as a significant problem for local governments.

The Czech government has shown some concern about local debt and has established regulations limiting deficit local finance, but this is because of a more general concern with the national debt (which under EU restrictions includes local debt). There is also specific concern for a very small number of local cases where debt has been imprudently incurred and managed (Bryson 2006 and 2006a; Ježek, Marková, and Váňa 2004, and Kling and Nižňanský 2004). The debt burden has generally been quite small, but it has grown somewhat over time. For the interested reader, these sources provide considerable data on the debt situation in the two republics; unfortunately, space considerations do not permit further elaboration here.

\section{The potential benefits of adopting a serious rather than a nominal property tax.}

All of the responses to questions in this core issue had answers with statistically significant differences.

\section{The issue of budget flexibility in Czech and Slovak cities and towns}

One view of budget flexibility and autonomy is that as resources available to municipalities increase over time, municipal officials have more choice. They have an increased ability to provide the most urgently needed public services and can spend more time making choices about what to do with additional funds that can provide greater amenities. At an early stage of development, the concern is with finding funds sufficient to provide even the most essential mandated services. Over time, greater funds provide greater budgetary choice and a sense of greater autonomy in the selection of services desired by the local citizenry. This seems to explain the perspective of many of our survey respondents. The authors, however, consider autonomy to be a function of making choices at every level of development with fiscal independence being reflected in the disposition of funds without any strings attached, funds raised by the municipality itself. Here, too, affluence provides greater budget flexibility, but we add the consideration that own revenues provide some additional space for autonomy.

In addressing the issue of budget flexibility, expressed both in the planning and management of local budgets, we search for some of the perceptions of autonomy such flexibilities help produce. Question 15 in Table 13 addresses the flexibility of local budgeting and relates to the following proposition: where central strings are attached to shared 
taxes or grants, budget flexibility is reduced. Funds would then generally be spent for the exclusive purpose of the transfer.

Table 13 here

Of Czech local officials, $47.4 \%$ agreed and $7.2 \%$ agreed strongly that they are able to use their funds flexibly for different purposes according to their own preferences. But $19.8 \%$ of them disagreed and $2.2 \%$ disagreed strongly that this option was open to them. In Slovakia, $54.3 \%$ agreed (of these, $12.6 \%$ did so strongly) that they could draw from any revenue source freely for whatever purposes, but $28.3 \%$ disagreed and another $3.3 \%$ strongly disagreed. Thus, somewhat fewer Slovaks saw budgeting for specific expenditures as a process of putting revenue from all sources into a single pot, then drawing from the pot to finance their preferred expenditures.

Question 16 asks specifically about the "pooling revenue sources and spending with discretion" (PRS/SWD) approach to budgeting. A chin-dropping 95\% of Czech local officials claimed that they do this. In Slovakia, local officials likewise claimed in large numbers (73\% of their respondents agreed and another $19 \%$ agreed strongly, which totals $92 \%$ ) that this is how their budgeting is done.

Question 18. In your budget do you use the same funding sources to finance particular expenditures each year?

\section{Czech Republic: Yes 86\%; No $7 \%$ \\ Slovak Republic: Yes $90 \%$; No. $5 \%$}

Question 18 was designed to determine whether local officials tended to tap funds from specific sources for designated purposes each budget year. Positive responses ranged from 86\% (Czech) to 90\% (Slovak) for this question. This question represents another way of asking whether the PRS/SWD method is not applied. Using the same revenue sources for the same expenditure purposes each year implies they are not pooling the funds, but taking education expenditures from transferred education funds, highway expenditures from grants or credits for highways, etc.

This seems to contradict responses to question 16, which indicate a pooling of financial resources to fund the projects they will stretch to cover. It is likely that both questions were loosely interpreted in the minds of respondents so that no contradiction was apparent to them. They seem to imply the following: "Yes, we add up all the numbers to see how many projects can be financed and what services can be provided, but when we start assigning expenditures, we obviously must keep an eye on important expenditures funded by grants requiring specified funding levels." In light of these responses, it appears we would have to look at specific budgets to draw conclusions about which ones provide greater flexibility for budget officials.

This concludes the discussion of the survey questions. It is interesting that the answers were generally very reflective and provided grist for considerable contemplation and analysis. But there were a few cases where the respondents' answers were shaded by emotional rather than reflective perceptions, as was the case when both Czechs and Slovaks generally responded that they functioned in a wholly autonomous manner, but that it would be nice if, in effect, their budgets were not hedged about with such extensive controls, limits, mandates and constraints. 
Many of our suspicions were confirmed through these responses, and many new insights gave rise to new questions that can direct future research.

\section{Conclusions}

The most significant differences in the responses of the Czech and Slovak local officials were as follows:

1. The Czechs were more strongly convinced that they were victims of unfunded mandates.

2. A larger share of the Czechs agreed that the funds transferred to them by the central government were sufficient to cover their current operating costs.

3. A slightly larger share of Slovak officials felt that they were supplying some public services that the central government should supply.

4. A larger percentage of Czech respondents felt that their central government supplied no services that the municipalities should be supplying.

5. Czech respondents believed a larger share of transferred funds could be spent at their own discretion than respondents of the Slovak Republic (Table 12).

6. A larger share of the Czech officials (37\%) felt a more significant property tax should be administered by the central government than was the case for Slovak officials ( $0 \%)$.

7. A larger share of the Czech respondents were convinced that the revenues from a property tax planned and designed by local self-governments would have a higher value to them than the same amount of revenues offered from the central government in the form of shared taxes.

No statistically significant differences were found between the Czech and Slovak respondents (it was as though they

were from the same statistical population) regarding the following questions:

1. Our municipality could operate with much greater independence if we were not so dependent upon financial transfers.

2. A strong majority of both groups disagreed with the statement that their municipality always had sufficient funds to accomplish the tasks expected of them.

3. Strong majorities from both countries' respondents agreed that funds received from all sources had not permitted them to make investments in capital facilities that would provide such things as schools, social services, and garbage collection at a satisfactory level in the future.

4. Strong majorities from both countries felt that municipal debt burdens did not provide significant problems for their financial situations.

5. The majority of respondents from both countries felt that they had the budgeting flexibility to substitute expenditures from other areas if funds fell short in a particular area of expenditures.

6. Very large majorities in both countries expressed the flexibility to pool all receipts and draw from the pool to make desired expenditures, yet

7. Almost all the respondents indicated that they used the same funding sources to finance particular expenditures each year.

Testing the general themes of fiscal decentralization against the perceptions of local officials in the Czech and Slovak Republics was an instructive exercise. The responses to the survey were a reflection of fiscal reality from the viewpoint of the insider as opposed to the outsider. The outside view has been that fiscal decentralization was an absolute necessity after the hyper-centralization of the former era. The successive central governments of both republics representing diverse political persuasions have paid lip service to the need for devolution of power, which was necessary to work with interested political influences emanating from the OECD, NATO, WTO, IMF and, most formidably, the EU. But sometimes policy and, even more especially, policy implementation has not clearly promoted fiscal decentralization. To understand these countries, the political views of their central governments 
must be considered. But possibly an even more important input is that of local officials expressing their perception of intergovernmental fiscal relations and subnational views on particular issues of fiscal decentralization.

It is extremely important to realize that the central government's dominating role is constitutionally guaranteed in the twin republics. The rather arbitrary assignment of "state administration" to the centre, i.e., the assignment to the centre of many tasks normally considered municipal tasks, unnaturally limits the role of municipalities to performing the residual menu of functions characterized as "self-government" (samospravy). This was presumably done because of the concern of national policymakers that many municipalities are too small and resource poor to function effectively.

When local officials are asked about the performance of their functions, it is apparent that the concept of state administration is thoroughly rationalized in their psyche. In some respects they are perfectly content with having the centre performing all those traditional functions that mayors (or governors) elsewhere would deem their rightful political domain. Such public officials are somewhat like a housewife who has a maid to perform many tasks of which she is most pleased to be relieved. But the question of sovereignty and ownership of rights should ultimately arise. What will happen, for example, if the maid not only reduces the burdens of the housewife through the performance of tedious and laborious tasks, but also begins removing the children of the household from private schools and placing them in public schools and/or starts ordering new furniture for the house? Sometimes local officials are delighted with having the centre responsible for performing tasks they could be "stuck with," such as when the Czech central government tells citizens how much property tax they must pay and then also collects it. Sometimes local authorities chafe at central intervention; sometimes they embrace it. Intergovernmental fiscal institutions can become a well-established tradition that seems to require no more justification than that they are ordained by the constitution or national law.

The survey revealed that, according to the perceptions of local officials, their political autonomy is related to the availability of sufficient funds both to meet contractual needs (such as the implementation of specific projects or the delivery of particular, contracted public services) and to be able to have some choice in the selection of the activities and services on the agenda. In the Czech and Slovak Republics, most of the transition period since 1989 has been characterized by having very few resources that had not been supplied by central government. The lack of own funds seems to the present authors to imply precious little autonomy, something supported by the fiscal decentralization literature focusing on these two countries. But this is not apparently a huge problem for municipal officials there. They would like more funds and apparently perceive that as the key to more choice; they are far less anxious to have substantially increased own revenues to enhance choice, especially if they have to provide the fiscal effort to produce such funds. There are, of course, many local officials who would not fit this general description and who would be perfectly happy to accept the responsibility and the effort of pursuing autonomous sources of funding. But the overall feeling is one of acceptance of the tradition as a fact of life not subject to political alteration.

A number of political implications seem to arise from these findings. Generally speaking, there is still considerable room for more serious decentralization. The Republic of Slovakia seems to be pursuing this more actively than the Czech Republic, which is momentarily preoccupied with pressing fiscal items at the central level; excessively ambitious pension and health care aspirations have caused budget strains that press against EU 
institutional restraints. The Slovaks have similar problems, but are pursuing them with more creative fiscal innovations that have been widely reported in the public media. There is plenty of room for the adoption of a variety of additional user fees and a more serious property tax. Both of these are less likely for the intermediate term for the Czech Republic.

Finally, when one considers the composition of the responses to our survey, it should be noted that the number of respondents was tilted to smaller cities and towns. The number of large cities participating was not great and our initial research indicates that some interesting findings might be teased out of the data by additional analysis focusing more intently on city size. Such research will be forthcoming, but it need not be expected that it will negate any of the findings of this paper. 


\section{Sources}

Bahl, R, and S. Wallace (1994) "Revenue Sharing in Russia," Environment and Planning C: Government and Policy 12, 293-307.

Bird, R. M., R. D. Ebel, C. I. Wallich (1995) Decentralization of the Socialist State: Intergovernmental Finance in Transition Economies (World Bank, Washington, D.C.).

Bish, R. L. and R. J. Kirk (1974) Economic Principles and Urban Economics (Prentice Hall, Englewood Cliffs, NJ). Bryson, P. J. (2006) “Local Debt in the Context of Decentralization and Reform: The Slovak Republic", presented at the $14^{\text {th }}$ NISPAcee Conf in Ljubljana, Slovenia.

Bryson, P. J. (2006) “Local Debt in the Czech Republic,” forthcoming.

Phillip J. Bryson, P.J., and G.C. Cornia (2006) “Slovakia’s Surge: The New System's Impact on Fiscal

Decentralisation," Post-Communist Economies, 18, 4, 451-471.

Bryson, P. J., G. C. Cornia and G. W. Wheeler, 2004, "Fiscal Decentralization in the Czech and Slovak Republics: A Comparative Study of Moral Hazard," Environment and Planning C: Government and Policy, 22, 103-113.

Bryson, P. J. and G. C. Cornia (2003) "Moral Hazard in Property Tax Administration: A Comparative Analysis of the Czech and Slovak Republics," Comparative Economic Studies, 45, 44-62.

Bryson, P. J. and G. C. Cornia (2002) "Geld en gemeenten: Fiscale Decentralisatie in Tsjechie en Slowakije “ (The Fiscal Situation in Communities: Fiscal Decentralization in the Czech and Slovak Republics), Oost-Europa Verkenningen, 168, 36-49.

Bryson, P. J. and G.C. Cornia (2001) “Taxes on Real Property in the Czech Republic”, in: J. Malme and J. Youngman (eds) (2001) 39-50.

Bryson, P. J. and G.C. Cornia (2001a), "Land and Building Taxes in the Republic of Slovakia, in: J. Malme and J. Youngman (eds) (2001) 51-56.

Bryson, P.J. and G. C. Cornia (2000) "Fiscal Decentralization in Economic Transformation: The Czech and Slovak Cases," Europe-Asia Studies, 52:3, 507-522.

Holzman, R. (1992). "Tax Reform in Countries in Transition: Central Policy Issues”, Public Finance/Finances

Publiques, Vol. 47, 3.

Ježek, V., H. Marková, and L. Váňa (2004) "Local Government Borrowing in the Deregulated Market of the Czech Republic,” in: P. Swianiewicz, (ed) (2004) 131-174.

Kelly R, 1994, Implementing property-tax reform in transitional countries: the experience of Albania and Poland, Environment and Planning C: Government and Policy, 12, 319-331.

Kling, J. and V. Nižňanský (2004) "From Deregulation to Regulation and Stabilization in Slovakia," in: P. Swianiewicz (ed.) (2004) 175-226.

Litvak, J. I., R.M. Bird, and J.Ahmand, (1998) Rethinking Decentralization in Developing Countries. (World Bank, Washington, D.C.).

J. Malme and J. Youngman (eds) (2001) The Development of Property Taxation in Economies in Transition: Case Studies from Central and Eastern Europe, (Washington, D.C., World Bank).

Matoušková, Z. (1998) “Malé obce potřebuji dotace,” OBEC a Finance, 5, 18-21. 
McLure C, Jr. (ed.) (1993). Tax Assignment in Federal Countries (Canberra, Centre for Research on Federal Financial Relations, Australian National University) 2-19.

Ministry of Finance, Republic of Slovakia (2005) Submitting Report (Bratislava, Slovakia). Available at http://www.finance.gov.sk/en/Default.aspx?CatID=310.

Musgrave R, 1993, "Who Should Tax, Where, and What," in McLure C, Jr., (ed.) (1993).

Oates, W. E., 1998, Introduction, in: W. E. Oates (ed.) The Economics of Fiscal Federalism and Local Finance

(North Hampton, Mass, Edward Elgar Publishing, Inc.,), xiii-xix.

Oates, W.E. (1998) “Introduction,” in W. E. Oates (ed.) (1998).

Oates W. E. (1996) "Taxation in a Federal System: The Tax-Assignment Problem," Public Economics Review $1(1), 35-60$.

Oates, W,E. (1972) Fiscal Federalism (New York: Harcourt Brace Jovanovich).

OECD Centre for Tax Policy and Administration, (2002). Fiscal Decentralisation in EU Applicant States and Selected EU Member States, Paris.

Oliveira, J. do C. and J. Martinez-Vazques (2001) Czech Republic: Intergovernmental Fiscal Relations in the Transition (Washington, DC, World Bank).

Swianiewicz, P. (ed.) (2004) Local Government Borrowing: Risks and Rewards: A Report on Central and Eastern Europe, (Budapest, Open Society Institute).

Tanzi V. (1991) Public Finance in Developing Countries (Aldershot, England, Edward Elgar Publishing Limited). Tiebout C. (1956) “A Pure Theory of Local Expenditures,” Journal of Political Economy 54(5), 416-424.

Von Hagen, J., M. Bordignon, M. Dahlberg, B.S. Grewal, P. Petterson and H. Seitz (2000) Subnational Government Bailouts in OECD Countries: Four Case Studies. Research network Working paper \#R-399, Inter-American Development Bank, Washington, D.C. 
Table 1

National and Local Budgets for Select Years: Czech Republic

\begin{tabular}{|l|r|r|r|r|r|r|r|r|r|}
\hline Year & 1993 & 1995 & 1996 & 1998 & 1999 & 2000 & 2004 & 2005 & \\
\hline Local Budget as \% of National Budget & 25.45 & 29.34 & 33.5 & 30.8 & 30.9 & 32.6 & 29.13 & 28.78 & 3 \\
\hline State Grants to Local Budgets* & 27.03 & 33.28 & 59.44 & 37.39 & 41.43 & 46.05 & 24.96 & 31.6 & \\
\hline Grants as \% of Local Budgets & 29.67 & 25.77 & 36.75 & 23.79 & 22.07 & 25.33 & 8.08 & 9.44 & \\
\hline Total Local Revenues* & 101 & 129 & 162 & 162 & 188 & 181 & 309 & 335 & \\
\hline Local Budget Expenditures* & 90.1 & 132.3 & 171.1 & 158 & 173 & 190 & 231 & 246 & \\
\hline National Budget Tax Revenues* & 224.6 & 255.4 & 283 & 495 & 524 & 544 & 963 & 1060 & \\
\hline Local Budget Tax Revenues* & 35.97 & 70.679 & 72.67 & 83.32 & 87.01 & 95.81 & 166.7 & 216.14 & 17 \\
\hline Real Estate Tax* & 3.021 & 3.799 & 4.018 & 4.108 & 4.248 & 4.437 & 4.919 & 4.966 & 4 \\
\hline RE Tax as \% of Local Revs & 2.99 & 2.95 & 2.48 & 2.53 & 2.26 & 2.44 & 1.59 & 1.48 & \\
\hline
\end{tabular}

Table 2

Unfunded Mandates

Question 6. In my experience, no mandates from the central government have been given unless public moneys were transferred to fund them. (The Czech version added: "This question does not refer to tasks of state administration.")

CZ: $\quad$ SA: $4 \%$

A: $7 \%$

U: $9 \%$

D: $52 \%$

SD: $28 \%$

SR: $\quad$ SA: $5 \%$

A $: 33 \%$

$\mathrm{U}: 14 \%$

D : $37 \%$

SD : $11 \%$

SA: Strongly Agree; A: Agree; U: Uncertain (Unable or unwilling to say); D: disagree; SD: strongly disagree.

Table 3

Test for Equality of Variances, Question 6

\begin{tabular}{|c|c|c|c|c|c|c|c|c|}
\hline & \multicolumn{3}{|c|}{$\begin{array}{c}\text { Levine's Test Equality of } \\
\text { Variances }\end{array}$} & \multicolumn{5}{|c|}{ t-test for Equality of Means } \\
\hline $\begin{array}{l}\text { Question } \\
\text { Number }\end{array}$ & $\begin{array}{l}\text { Test } \\
\text { Assumption }\end{array}$ & $\mathrm{F}$ & Prob. & $\mathrm{T}$ & $d f$ & $\begin{array}{l}\text { Sig. } \\
(2- \\
\text { tailed })\end{array}$ & $\begin{array}{c}\text { Mean } \\
\text { Difference }\end{array}$ & $\begin{array}{l}\text { Std. Error } \\
\text { Difference }\end{array}$ \\
\hline $\begin{array}{l}\text { 6. Mandates } \\
\text { are Tied to } \\
\text { Funding }\end{array}$ & $\begin{array}{l}\text { Unequal } \\
\text { variances } \\
\text { assumed }\end{array}$ & 5.02 & 68.667 & .000 & .809 & .161 & .488 & 1.131 \\
\hline
\end{tabular}


Table 4

Resources to Cover Operating Costs

Question 4. From all financial resources, we receive at least enough revenue to cover our annual operating costs.
CZ: $\quad$ SA: $11 \%$
A: $63 \%$
$\mathrm{U}: 1 \%$
D: $20 \%$
SD: $5 \%$
SR: $\quad$ SA: $2 \%$
A: $50 \%$
$\mathrm{U}: 8 \%$
D: $40 \%$
SD: $0 \%$

Table 5

Test for Equality of Variances, Question 4

\begin{tabular}{|l|l|l|c|c|c|c|c|c|}
\hline & \multicolumn{2}{|c|}{ Levine's Test Equality of Variances } & \multicolumn{4}{|c|}{ t-test for Equality of Means } \\
\hline $\begin{array}{l}\text { Question } \\
\text { Number }\end{array}$ & $\begin{array}{l}\text { Test } \\
\text { Assumption }\end{array}$ & $\mathrm{F}$ & Prob. & $\mathrm{T}$ & $d f$ & $\begin{array}{l}\text { Sig. (2- } \\
\text { tailed) }\end{array}$ & X dif & se dif \\
\hline $\begin{array}{l}\text { 4. Revenue to } \\
\text { Cover } \\
\text { Operating } \\
\text { Costs }\end{array}$ & $\begin{array}{l}\text { Equal } \\
\text { variances } \\
\text { assumed }\end{array}$ & .118 & .732 & -2.752 & 437 & .006 & -.416 & .151 \\
\hline
\end{tabular}

Table 6

Questions on the Appropriate Service Supplier

Services Better Supplied by the Centre or Regions

Question 8. My local government never supplies services that would be better supplied by the central or regional government. (In the Czech Survey: "This question does not include tasks of state administration.")
CZ: $\quad$ SA: $7.2 \%$
A: $47.4 \%$
$\mathrm{U}: 23.4 \%$
D: $19.8 \%$
SD: $2.2 \%$
SR: $\quad$ SA: $10 \%$
A: $42 \%$
$\mathrm{U}: 17 \%$
D: $28 \%$
SD: $3 \%$

Appropriate Local Service Supply

Question 9. The central and/or regional governments supply no public services that would be better to supply through independent, local governments.
CZ: $\quad$ SA: $6.9 \%$
A: $48.7 \%$
U. $21.7 \%$
D: $20.6 \%$
SD: $2.1 \%$
SR: $\quad$ SA: $7 \%$
A: $22 \%$
$\mathrm{U}: 33 \%$
D: $33 \%$
SD: $5 \%$ 
Table 7

Test for Equality of Variances, Question 13

Central Government Revenue Percentage

\begin{tabular}{|l|l|c|c|c|c|c|c|c|}
\hline & \multicolumn{3}{|c|}{\begin{tabular}{c}
\multicolumn{5}{c|}{ Levine's Test Equality of } \\
Variances
\end{tabular}} & \multicolumn{5}{c|}{ t-test for Equality of Means } \\
\hline & $\begin{array}{l}\text { Test } \\
\text { Assumption }\end{array}$ & $\mathrm{F}$ & Prob. & $\mathrm{T}$ & $d f$ & $\begin{array}{c}\text { Sig. }(2- \\
\text { tailed) }\end{array}$ & X dif & SE dif \\
\hline $\begin{array}{l}\text { Question Number Central } \\
\begin{array}{l}\text { Government } \\
\text { Revenue } \\
\text { Percentage }\end{array}\end{array}$ & $\begin{array}{l}\text { Unequal } \\
\text { variances }\end{array}$ & 5.604 & .018 & $-3,591$ & 77.752 & .001 & -15.92 & \\
\end{tabular}

Table 8

Test for Equality of Variances, Question 12

\begin{tabular}{|c|c|c|c|c|c|c|c|c|}
\hline & \multicolumn{3}{|c|}{$\begin{array}{c}\text { Levine's Test Equality of } \\
\text { Variances }\end{array}$} & \multicolumn{5}{|c|}{ t-test for Equality of Means } \\
\hline Question Number & $\begin{array}{l}\text { Test } \\
\text { Assumption }\end{array}$ & $\mathrm{F}$ & Prob. & $\mathrm{t}$ & $d f$ & $\begin{array}{c}\text { Sig. } \\
(2- \\
\text { tailed) }\end{array}$ & $\begin{array}{c}\text { Mean } \\
\text { Difference }\end{array}$ & $\begin{array}{l}\text { Std. Error } \\
\text { Difference }\end{array}$ \\
\hline $\begin{array}{l}\text { 12. Locally } \\
\text { Administered } \\
\text { Real Estate Tax }\end{array}$ & $\begin{array}{l}\text { Unequal } \\
\text { variances } \\
\text { assumed }\end{array}$ & 226.9 & .000 & 12.348 & 121.29 & .000 & .548 & .044 \\
\hline
\end{tabular}

Table 9

Questions on the Potential Value of the Property Tax

Property Tax as Revenue Source

Question 11. It seems logical to me that, as in England or the United States, a real estate tax, effectively designed and administered, could be a source of considerable revenue for local governments.
CZ: $\quad$ SA: $19 \%$
A: $47 \%$
$\mathrm{U}: 24 \%$
D: $9 \%$
SD: $1 \%$
SR: $\quad$ SA: $12 \%$
A: $55 \%$
$\mathrm{U}: 26 \%$
D: $7 \%$
SD: $0 \%$

Perceived Value of Local property tax

Question 14. Revenues from a property tax planned and designed by local self-governments would have a higher value to us than the same amount of revenues offered from the central government in the form of shared taxes.
CZ: $\quad$ SA: $10 \%$
A: $42 \%$
U: $29 \%$
D: $16 \%$
SD: $2 \%$
SR: $\quad$ SA: $10 \%$
A: $24 \%$
U: $31 \%$
D: $29 \%$
SD: $7 \%$ 
Table 10

Test for Equality of Variances, Question 14

\begin{tabular}{|l|l|c|c|c|c|c|c|c|}
\hline & \multicolumn{3}{|c|}{$\begin{array}{l}\text { Levine's Test Equality of } \\
\text { Variances }\end{array}$} & \multicolumn{4}{c|}{ t-test for Equality of Means } \\
\hline & $\begin{array}{l}\text { Test } \\
\text { Assumption }\end{array}$ & $\mathrm{F}$ & Prob. & $\mathrm{t}$ & $d f$ & $\begin{array}{l}\text { Sig. (2- } \\
\text { tailed) }\end{array}$ & $\mathrm{X}$ dif & Se dif \\
\hline $\begin{array}{l}\text { Question Number } \\
\text { Pigher Value of Locally }\end{array}$ & $\begin{array}{l}\text { Equal } \\
\text { Variances } \\
\text { Assumed }\end{array}$ & 0.569 & 0.451 & -2.931 & 433 & .004 & -.401 & .137 \\
\hline
\end{tabular}

Table 11

Questions on Local Autonomy

Views on Autonomous Operation

Question 1. Although our municipality receives most of our revenues from the central government, we operate with complete autonomy.

CZ: $\quad$ SA: $14 \%$

A: $53 \%$

$\mathrm{U}: 3 \%$

D: $24 \%$

D : $27 \%$

SD: $6 \%$

SR: $\quad$ SA: $11 \%$

A : $56 \%$

$\mathrm{U}: 2 \%$

SD : $3 \%$

Dependence on Financial Transfers

Question 2. Our municipality could operate with much greater independence if we were not so dependent upon financial transfers from the central government to fund our activities.
CZ: $\quad$ SA:33\%
A: $51 \%$
$\mathrm{U}: 5 \%$
D: $10 \%$
SD: $1 \%$
SR: $\quad$ SA: $25 \%$
A : $55 \%$
$\mathrm{U}: 8 \%$
D : $8 \%$
$\mathrm{SD}: 3 \%$

Sufficient Funds for Budget Autonomy

Question 10. Although we face many required expenditures, we still have enough funds to make me feel that we have budget autonomy and discretion.
CZ: $\quad$ SA: $4 \%$
A: $48 \%$
$\mathrm{U}: 3 \%$
D: $36 \%$
SD: $9 \%$
SR: $\quad$ SA: $7 \%$
A: $33 \%$
$\mathrm{U}: 3 \%$
D: $47 \%$
SD: $10 \%$

"Sufficient" Funds

Question 3. Our municipality always has sufficient funds to accomplish the tasks expected of us.
CZ: $\quad$ SA: $1 \%$
A: $11 \%$
$\mathrm{U}: 2 \%$
D: $52 \%$
D: $58 \%$
SD: $34 \%$
SR: $\quad$ SA: $0 \%$
A: $12 \%$
$\mathrm{U}: 3 \%$
SD: $27 \%$

Funds for Capital Investments

Question 5. In the past ten years, funds we have received from all sources have permitted us to make investments in capital facilities that will enable us to provide necessary functions such as schools, social services, and garbage collection, at a satisfactory level in the future.
CZ: $\quad$ SA: $3 \%$
A: $23 \%$
$\mathrm{U}: 3 \%$
D: $51 \%$
SD: $20 \%$
SR: $\quad$ SA: $5 \%$
A: $16 \%$
U: $7 \%$
D: $61 \%$
SD: $16 \%$ 
Table 12

The Debt Burden

Question 7. The debt burden of our local self-government is appropriate and payments of principal and interest during the repayment period do not cause significant problems with fulfillment of financial obligations which accrue to us by extant legal norms.

$\begin{array}{llllll}\text { CZ: } & \text { SA: } 23 \% & \text { A: } 60 \% & \text { U: } 3 \% & \text { D: } 12 \% & \text { SD: } 2 \% \\ \text { SR: } & \text { SA: } 15 \% & \text { A: } 62 \% & \text { U: } 7 \% & \text { D: } 12 \% & \text { SD: } 5 \%\end{array}$

\section{Table 13}

Questions on Budget Flexibility

\section{Expenditures Flexibility}

Question 15. If expenses for one function, e.g., social care, increased rapidly, we could meet those costs by spending less for one or more other functions, e.g., education, sport, culture or transportation, according to our own preferences.
CZ: $\quad$ SA: $7.2 \%$
A: $47.4 \%$
U: $23.4 \%$
D: $19.8 \%$
SD: $2.2 \%$.
SR: $\quad$ SA: $12.6 \%$
A: $41.7 \%$
$\mathrm{U:} 16.7 \%$
D: $28.3 \%$
SD: $3.3 \%$

Revenue Pooling and Discretionary Spending

Question 16. In making budgetary decisions, we pool all revenue sources to determine the total amount available for all expenditures, and then we spend the entire pool on activities and projects according to our own discretion.

\begin{tabular}{llllll} 
CZ: & SA: $27 \%$ & A: $68 \%$ & U: $1 \%$ & D: $4 \%$ & SD: $1 \%$ \\
SR: & SA: $19 \%$ & A: $73 \%$ & U: $5 \%$ & D: $3 \%$ & SD: $0 \%$ \\
\hline
\end{tabular}

\footnotetext{
${ }^{1}$ Another set of inquiries regarding the specific breakdown of municipal expenditures fell under the rubric of question 17. The responses to that complex of questions yielded a large amount of data that suggest the subject of another paper. That set of issues, therefore, will not be discussed here.

2See Holzman's "Tax Reform in Countries in Transition”, op. cit., p. 242, which indicates that the Czech Republic also grants exemptions on the VAT for consumer goods "with detrimental consequences for tax revenue."
}

14. ${ }^{3}$ Although differences existed in the number of Czech and Slovak managers interviewed, each question considered for analysis had a sufficient number of responses for reliable statistical testing. In addition all analyses included a test for the equality of variances and depending on the outcome, the appropriate statistical method for testing differences between group mean values was selected and used. Unfortunately, we were not informed by the assisting 
associations how many municipals were requested to respond to the survey and are unable to say what the response percentage was. If the survey was sent to every municipality on line, the Slovak participation rate would have been around 5\%. All Slovak municipalities are not members of ZMOS, so with non-members not receiving the survey, the response rate would have actually been somewhat higher. Using the same reasoning for the Czech case, we would estimate the response rate around $12-15 \%$.

${ }^{4}$ By way of orientation, in 2005 the dollar exchanged for 24 crowns, whereas in 2002 the exchange rate had been 40 crowns per dollar. By November, 2007, the exchange rate was just under 18 crowns per dollar. In November of 2007 the Euro exchanged for 26.13 Czech crowns.

${ }^{5}$ The problem of bailouts has been carefully investigated by Von Hagen et al (2000) and they have illuminated some important sources of the problem in presenting four case studies of bailouts of subnational governments in Australia, Germany, Italy and Sweden. Their abstract reports that "the case studies show that bailouts can occur in a diverse set of institutions shaping the relations between central and subnational governments. Surprisingly, there is little evidence in favor of the "too big to fail" argument explaining bailouts. In contrast, elements of political favoritism play some role in most cases. The cases also indicate the importance of properly designing principal-agent relationships in the decentralization of public finances. Constitutional mandates for uniform provision of public services and attempts by the central government to dominate subnational governments in matters of fiscal policy seem to be conducive to bailouts."

${ }^{6}$ Our responses were coded with scores of 1 for SA, 2 for A, 3 for uncertain or unwilling to say, 4 for D and 5 for SD. Of the 373 responses included in the analysis for the Czech Republic, the mean response for Question one was 2.55 (standard deviation 1.162). For question 2 the mean response was 1.94 (standard deviation .915). The Pearson Correlation between question 1 ("we operate with autonomy") and question 2 ("we are dependent on financial transfers) was only -.059 and the significance of a 1-tailed test was .128, or insignificant at the .05 confidence level. Regressing the responses to Question 1 on Question 2 yields an $\mathrm{R}^{2}$ no greater than .003 , which is not significant at the .05 confidence level. This is interpreted to mean that the Czech responses to the two questions showed no statistically significant functional relationship. It was as though the two responses were from different groups, i.e., they were answered from two completely different perspectives. It was as though one group of people was explaining in question 1 that they had decision-making responsibilities and an important job to perform and another group was explaining in question 2 that their ability to function independently was curtailed significantly by their dependence upon centrally-provided and -managed financial resources.

For the Slovak case, the mean response for Question one was 2.58 (standard deviation 1.109). For question 2 the mean response was 2.10 (standard deviation .986). The Pearson Correlation between response 1 ("we operate with autonomy") and response 2 ("we are dependent on financial transfers) was only .101, only a little higher than the Czech case, and the significance of a 1-tailed test was also a little higher at .222, but still far from significant at the .05 confidence level. Regressing the responses to Question 1 on Question 2 yields an $\mathrm{R}^{2}$ no greater than .010, which is not significant at the .05 confidence level. This analysis yields the same result as that of the Czech Republic. T- 
tests of the means of samples for the two countries failed to demonstrate any statistical difference between their means. 